\title{
DISTRIBUTION OF THE ABO AND RHESUS (D) BLOOD GROUPS IN THE NORTH OF SCOTLAND
}

\author{
ELIZABETH S. BROWN \\ North of Scotland Blood Transfusion Service, Inverness
}

\section{INTRODUCTION}

Received 4 .xii.6 4

ThE distribution of $A B O$ blood groups in the north of Scotland was first studied by Kirkpartick in $195^{2}$ and his figures were included in the tables and maps of world distribution compiled by Mourant and Kopeć. $^{5}$ Those figures were obtained from analysis of the record cards of blood donors arranged according to places of residence at that time. While many people now resident in the north of Scotland were probably born there, or are at least of Scottish extraction, it was felt that a much more valuable survey could be made if it included only those individuals who were known to belong to the area. Accordingly, a project was launched in which blood donors in the
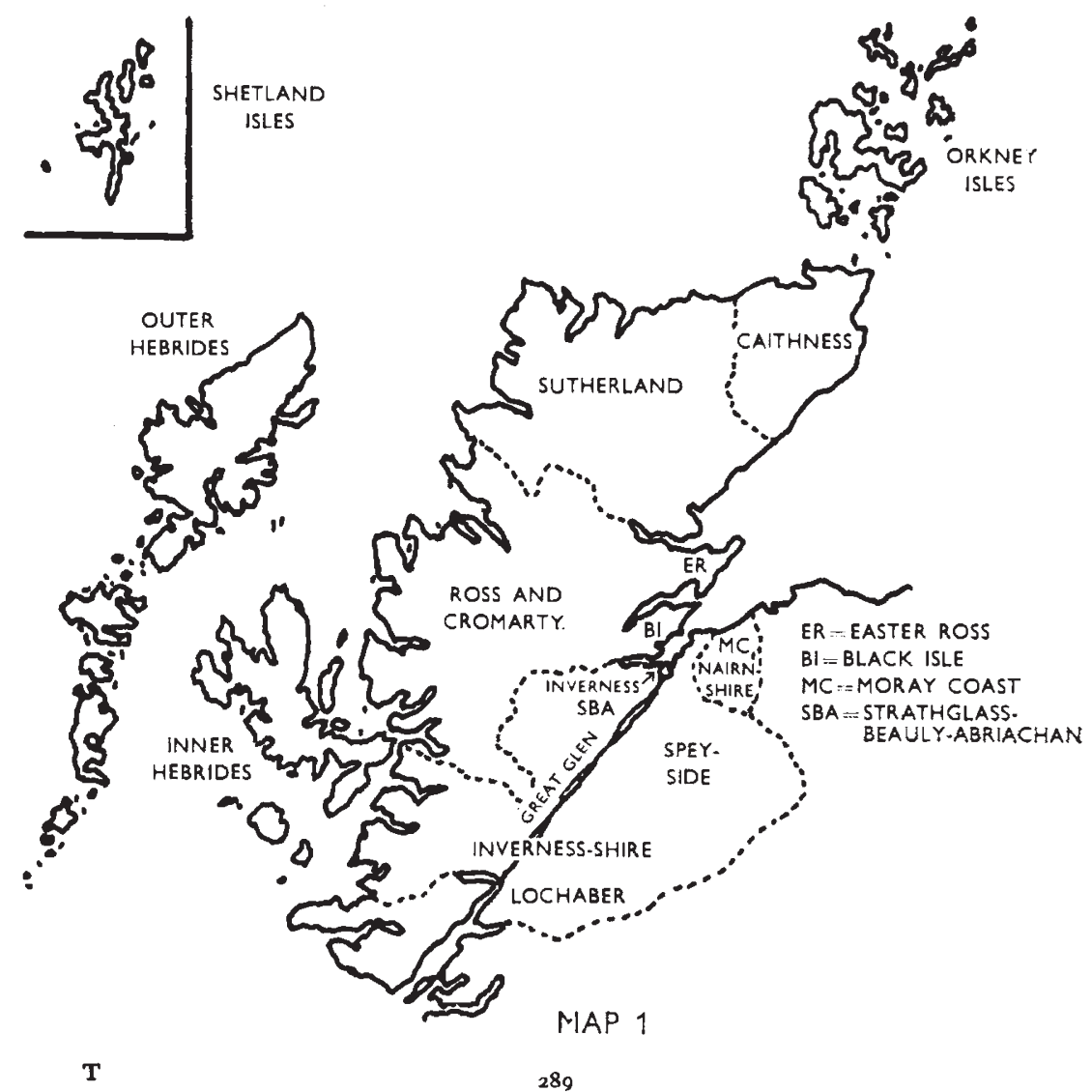
north of Scotland and in-patients in Inverness hospitals were questioned about their own and their grandparents' places of birth and the following study is based on the information thus obtained. The area covered, which has a total population of some 200,000, comprises the Orkney and Shetland Islands and the five most northern counties of Scotland, namely Caithness, Sutherland, Ross and Cromarty, Inverness-shire and Nairn-shire, and includes those islands of the Outer and Inner Hebrides which are part of Ross and Inverness-shire (map I).

\section{MATERIAL AND METHOD}

The figures for the Shetland and Orkney Islands were obtained in connection with another project, and no information regarding ancestry was collected. It can be assumed, however, that a high proportion of these people will be native to the islarids.

For the rest the information was recorded on cards which were at first divided into two categories:-

(a) Those in which the birth-place of every grandparent was given and fell within the area.

(b) Those in which all four grandparents were known to have been born somewhere in the area, although their actual birth-places could not be given.

Analysis of the records of 1000 individuals whose grandparents' birth-places were known, showed that between 80 per cent. and 90 per cent. of them were born in the same neighbourhood as their grandparents. Where this was not so, from 5 to 20 per cent. had been born elsewhere in the five northern counties. The sum of the two percentages never fell below 90 per cent. In most cases it was 95 per cent., and in Wester Ross 99 per cent. It was therefore considered justifiable to combine the two categories and thus obtain larger numbers for analysis in each locality.

Subdivision of the area has been achieved by two methods. (i) In the eastern part of the region, where the bulk of the population is situated, cards were sorted out according to small communities and those for adjacent localities showing similar trends in the distribution of blood groups were then combined, always however, with due regard to the topography of the countryside. (ii) The second method was mainly geographical. The groups of islands formed obvious subdivisions, as did the northern and western coastal strips where, with the exception of Fort William at the south-western end of the Great Glen, centres of population are little more than hamlets. Coastal strips were taken as extending five miles inland. County boundaries have been used mainly as a convenient method of breaking up rather large tracts of country, e.g. the west coast and inland areas north and west of the Great Glen. where they also have some significance as ancient territorial boundaries. Two special areas in the east have been selected as units-namely Easter Ross, and the Black Isle-where the people are known to be particularly closely-knit. Lastly, there is a subdivision designated "East Coast Fishing", in which two or three grandparents were born in the fishing villages on the east coast of our area, and the others have come from fishing villages further east along the Scottish coast. This subdivision does not contain many cards, but the blood group distribution seemed sufficiently interesting to include them as a separate entity.

In Orkney and Shetland, householders were selected from the rate-payers' lists and the other subdivisions are generally composed of approximately equal numbers of blood donors and patients. In the remoter parts of the north and west, however, there are more patients than donors because normal maternity cases and patients suffering from potentially serious conditions are sent in to hospital to avoid the risk of dealing with complications in an isolated locality. There too, there are insufficiently large centres of population to support blood withdrawal sessions. This 
position is reversed in the district around Dingwall where there is a good hospital in which patients, who might otherwise have come to Inverness are looked after locally. There also, there are towns and villages where blood withdrawal sessions are held so that in this district the figures include more blood donors than patients.

TABLE

\begin{tabular}{|c|c|c|c|c|c|c|c|c|}
\hline & \multicolumn{3}{|c|}{ Percentages } & \multirow[b]{2}{*}{$A B$} & \multicolumn{4}{|c|}{ Gene frequencies } \\
\hline & $O$ & $A$ & $B$ & & $r$ & $p$ & q & Totals \\
\hline 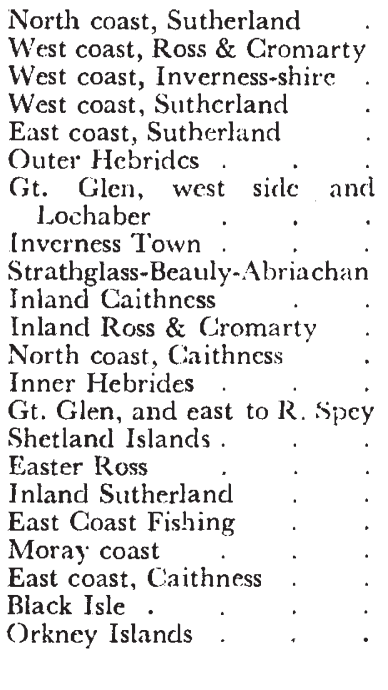 & $\begin{array}{l}62 \cdot 50 \\
62 \cdot 77 \\
63 \cdot 78 \\
61 \cdot 22 \\
58 \cdot 22 \\
57 \cdot 36 \\
55 \cdot 42 \\
55 \cdot 25 \\
52 \cdot 71 \\
54 \cdot 88 \\
54 \cdot 04 \\
53 \cdot 91 \\
53 \cdot 50 \\
51 \cdot 40 \\
51 \cdot 37 \\
50 \cdot 75 \\
47 \cdot 05 \\
45 \cdot 0 \\
46 \cdot 73 \\
44 \cdot 63 \\
42 \cdot 36 \\
45 \cdot 45\end{array}$ & $\begin{array}{l}26 \cdot 79 \\
3 \cdot 49 \\
23 \cdot 19 \\
18 \cdot 37 \\
27 \cdot 85 \\
33 \cdot 15 \\
31 \cdot 09 \\
31 \cdot 40 \\
27 \cdot 9 \\
30 \cdot 82 \\
31 \cdot 25 \\
28 \cdot 13 \\
34 \cdot 23 \\
29 \cdot 61 \\
32 \cdot 19 \\
28 \cdot 36 \\
38 \cdot 23 \\
28 \cdot 32 \\
35 \cdot 51 \\
36 \cdot 02 \\
38 \cdot 08 \\
33 \cdot 12\end{array}$ & $\begin{array}{r}10 \cdot 72 \\
6 \cdot 73 \\
10 \cdot 15 \\
14 \cdot 29 \\
10 \cdot 76 \\
6 \cdot 8 . \\
10 \cdot 81 \\
11 \cdot 09 \\
17 \cdot 82 \\
10 \cdot 52 \\
11 \cdot 03 \\
14 \cdot 06 \\
8 \cdot 72 \\
16 \cdot 76 \\
14.33 \\
14 \cdot 91 \\
13 \cdot 23 \\
23.33 \\
12 \cdot 14 \\
13 \cdot 98 \\
13 \cdot 98 \\
13.63\end{array}$ & $\begin{array}{l}- \\
2 \cdot 90 \\
6 \cdot 12 \\
3 \cdot 16 \\
2 \cdot 74 \\
2 \cdot 70 \\
3 \cdot 29 \\
1 \cdot 52 \\
3 \cdot 76 \\
3 \cdot 68 \\
3 \cdot 91 \\
3 \cdot 49 \\
2 \cdot 24 \\
2 \cdot 5 \cdot 3 \\
5 \cdot 37 \\
1 \cdot 47 \\
3 \cdot 33 \\
5 \cdot 61 \\
5 \cdot 38 \\
4 \cdot 66 \\
7.00\end{array}$ & $\begin{array}{l}79 \cdot 96 \\
79 \cdot 88 \\
79 \cdot 29 \\
76 \cdot 37 \\
75 \cdot 89 \\
75 \cdot 33 \\
74 \cdot 38 \\
74 \cdot 02 \\
73 \cdot 62 \\
73 \cdot 54 \\
73 \cdot 09 \\
73 \cdot 07 \\
72 \cdot 65 \\
72 \cdot 44 \\
7 \cdot \cdot 71 \\
70 \cdot 17 \\
69 \cdot 79 \\
68 \cdot 1 \\
67 \cdot 57 \\
66 \cdot 43 \\
65 \cdot 2 \cdot 4 \\
6 \cdot 56\end{array}$ & $\begin{array}{l}14.51 \\
16.69 \\
13.98 \\
19.96 \\
16.90 \\
19.82 \\
18.62 \\
18 \cdot 53 \\
16.10 \\
19.06 \\
19.28 \\
17.52 \\
21.07 \\
17.52 \\
19.66 \\
18.84 \\
22.51 \\
17.44 \\
23.26 \\
23.40 \\
24.95 \\
23.36\end{array}$ & $\begin{array}{r}5.54 \\
3.43 \\
6.73 \\
10 \cdot 67 \\
7.21 \\
4.84 \\
7.00 \\
7.45 \\
10.27 \\
7.39 \\
7.63 \\
9.41 \\
6.28 \\
10 \cdot 04 \\
8.63 \\
10.99 \\
7.70 \\
14.45 \\
9.27 \\
10.17 \\
9.81 \\
11.43\end{array}$ & $\begin{array}{r}56 \\
223 \\
69 \\
49 \\
158 \\
190 \\
74 \\
78 \\
487 \\
129 \\
133 \\
272 \\
128 \\
172 \\
179 \\
146 \\
134 \\
68 \\
60 \\
107 \\
186 \\
236 \\
154 \\
3410\end{array}$ \\
\hline
\end{tabular}

\section{GENE FREQUENCIES}

\section{(i) Frequency of the gene $O$ (map 2)}

The gene $O$ reaches its highest frequency on all three coasts of Sutherland, the west coasts of Ross and Inverness-shire and the Outer Hebrides. In all these areas the frequency is 75 per cent. or more. Only slightly lower are the Shetland Islands, Caithness (except for its east coast), the inland districts of Inverness-shire on both sides of the Great Glen, most of the remainder of Ross and the Inner Hebrides, where the frequency lies between 70-75 per cent. The lowest values (between 65-70 per cent.) occur on the east coast of Caithness, inland Sutherland, that part of Ross and Cromarty known as the Black Isle and the Moray coast. A frequency of over 75 per cent. has only been recorded elsewhere in the British Isles on the Denbigh coastal plain, in north Wales, by Watkin ${ }^{7}$ and in parts of Ireland. ${ }^{5}$ The low valucs for the east coast of Caithness and the Black Isle are comparable to those obtained in the Midlands and south of England and are not paralleled elsewhere in rural districts of Scotland. 
Inverness town comes quite high in the incidence of the gene $O$ (74.02 per cent.) which no doubt reflects a movement of population from remote districts in search of work.

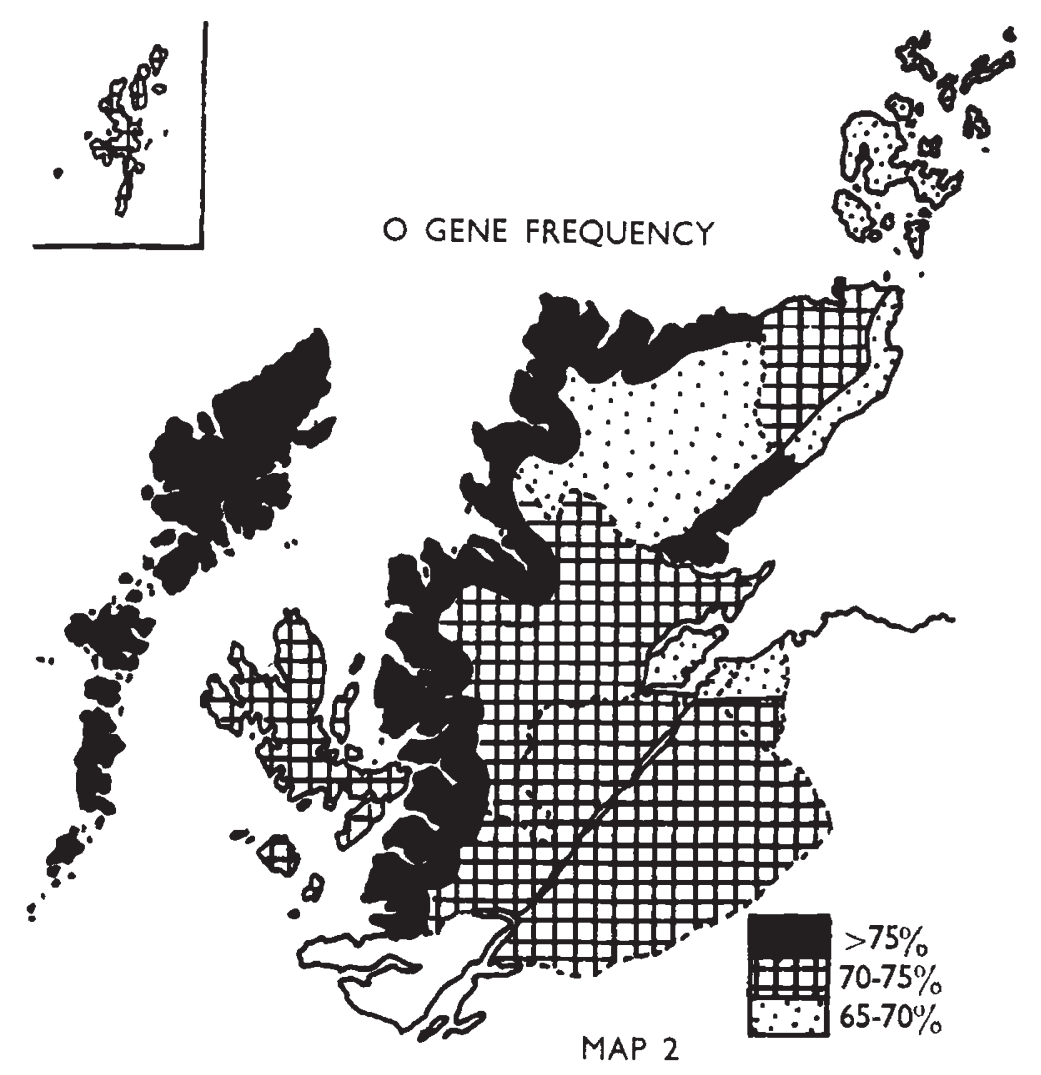

(ii) Frequency of the gene A (map 3)

The conclusion, first put forward by Fisher and Taylor ${ }^{1}$ in 1940, and since elaborated in more detail by Kopeć, ${ }^{2,3}$ that the frequencies of the genes $O$ and $A$ are reciprocal in the British Isles, is further supported by the findings in the north of Scotland, although the movement is more in an east-west direction in the country to the north of the Great Glen than north-south as is found elsewhere in Great Britain.

The highest values of $A$ (20-25 per cent.) are found in the Orkney Islands, east Caithness, inland Sutherland, the Black Isle and the Moray coast, which are the lowest $O$ areas. On the north and west coasts of Sutherland and the west coast of Inverness-shire the frequency of the gene $A$ is found to be lowest (IO-I 5 per cent.) and those are very high $O$ areas.

Between these extremes there are less marked differences but the 
general pattern of reciprocity holds good, as one travels north and west from the Great Glen. The areas of inland and east coast Sutherland are exceptions to this trend, but there may be a recent historical explanation for this.

The Hebrides do not continue the gradient from the adjacent mainland but echo the pattern within themselves-the Inner Hebrides having the higher $A$ level and lower $O$ and the Outer Hebrides presenting the reverse picture.

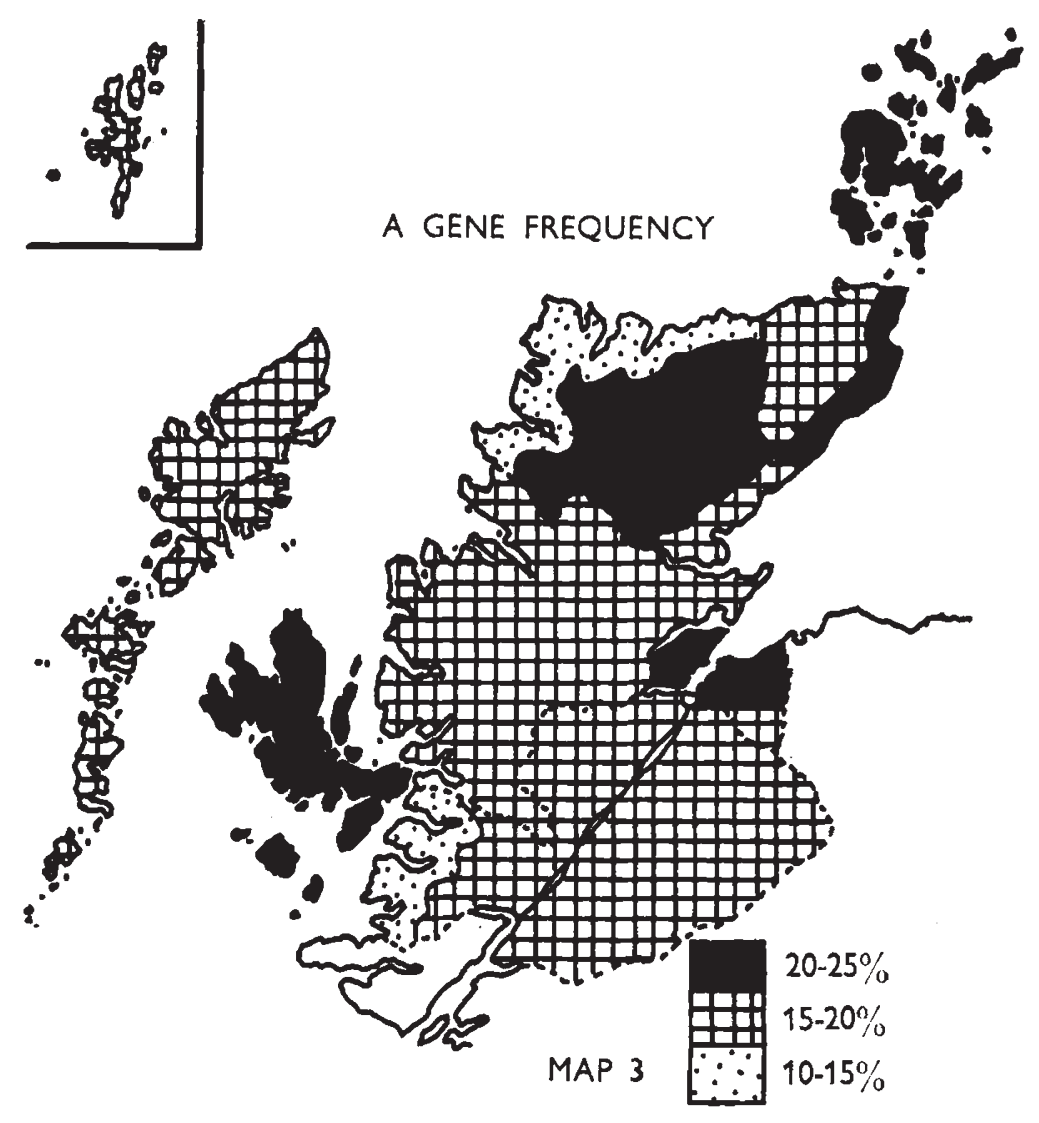

(iii) Frequency of the gene $B$ (map 4)

The north of Scotland is remarkable in having some districts with the lowest frequency of the gene $B$ in the British Isles and others which have the highest, only surpassed by the exceptionally high values in a few parts of Wales (Mourant and Watkin). ${ }^{6}$ In Wester Ross the incidence is only 3.43 per cent. and this is closely followed by the Outer Hebrides with 4.84 per cent. In both these areas the totals are in the neighbourhood of 200 (190 and 223 respectively) which should give a fair basis for calculation. The fact that the adjacent coast of west Sutherland presents one of the highest frequencies of the whole 
area (10.67 per cent.) is unexpected. Other very high districts are the Orkney Islands, east coast Caithness, Easter Ross, StrathglassBeauly-Abriachan and east Great Glen, with north coast Gaithness, the Black Isle and Moray coast almost as high. The east coast of Sutherland provides the only break in the zone of high $B$ frequencies along the eastern seaboard. Elsewhere the $B$ frequency does not vary much from the average for Great Britain as a whole.

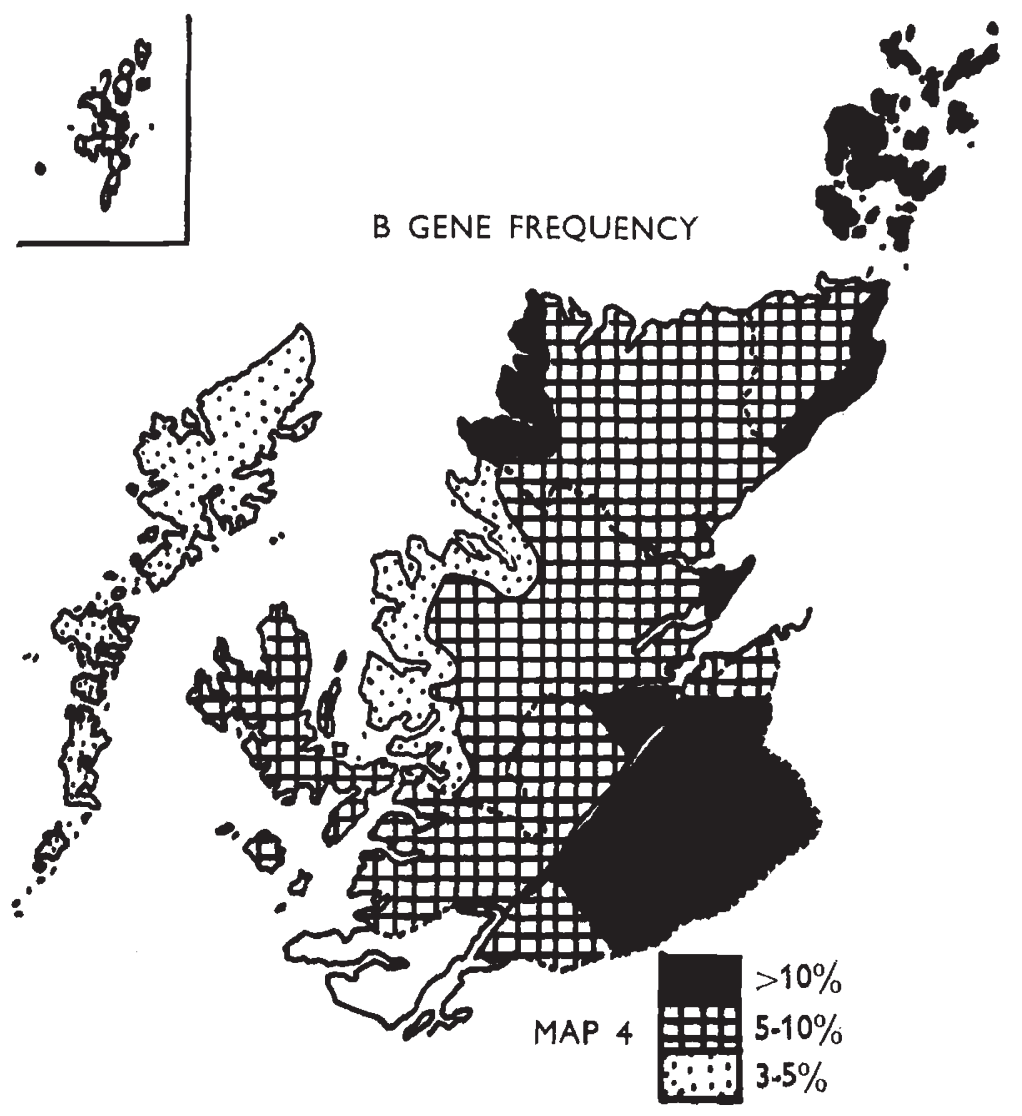

The class designated " East Coast Fishing" presents the highest $B$ frequency of all ( 14.45 per cent.). There were only 60 individuals in this subdivision but in addition to supporting the general high incidence of the gene $B$ on the east coast, the figures seem to point to a peculiar distribution within a community, which although scattered geographically, is closely knit socially.

\section{(iv) Comparison with 1952 figures}

An attempt was made to compare the foregoing frequencies of $O, A$ and $B$ with those found by Kirkpatrick in $195^{2}$, but this was only possible for Caithness, Sutherland and Stornoway (table 2). In other areas it was not clear where subdividing lines had been drawn. 
Application of the $\chi^{2}$ test to these figures shows that the differences are not statistically significant. Kirkpatrick's figures were calculated from the blood donor panels and were therefore based on place of

TABLE 2

\begin{tabular}{|c|c|c|c|c|c|c|c|c|}
\hline & $O$ & $A$ & $B$ & $A B$ & $r$ & $p$ & $q$ & Total \\
\hline $\begin{array}{l}\text { Caithness and Sutherland } \\
\text { (1952) } \\
\text { New figures (ditto) }\end{array}$ & $\begin{array}{l}50 \cdot 98 \\
54 \cdot 63\end{array}$ & $\begin{array}{l}32 \cdot 03 \\
29 \cdot 46\end{array}$ & $\begin{array}{l}13 \cdot 72 \\
12 \cdot 5 \mathrm{I}\end{array}$ & $\begin{array}{l}3.27 \\
3.4\end{array}$ & $\begin{array}{l}71 \cdot 53 \\
73 \cdot 68\end{array}$ & $\begin{array}{l}19.57 \\
18.03\end{array}$ & $\begin{array}{l}8 \cdot 90 \\
8 \cdot 29\end{array}$ & $\begin{array}{l}153 \\
788\end{array}$ \\
\hline $\begin{array}{l}\text { Stornoway (1952) } \\
\text { New figures-Outer Hebrides }\end{array}$ & $\begin{array}{l}50 \cdot 00 \\
57 \cdot 3^{6}\end{array}$ & $\begin{array}{l}32 \cdot 00 \\
33 \cdot 15\end{array}$ & $\begin{array}{r}14.50 \\
6.84\end{array}$ & $\begin{array}{l}3 \cdot 50 \\
2 \cdot 74\end{array}$ & $\begin{array}{l}70 \cdot 85 \\
75 \cdot 33\end{array}$ & $\begin{array}{l}19 \cdot 70 \\
19 \cdot 82\end{array}$ & $\begin{array}{l}9.45 \\
4.84\end{array}$ & $\begin{array}{l}200 \\
190\end{array}$ \\
\hline
\end{tabular}

TABLE 3

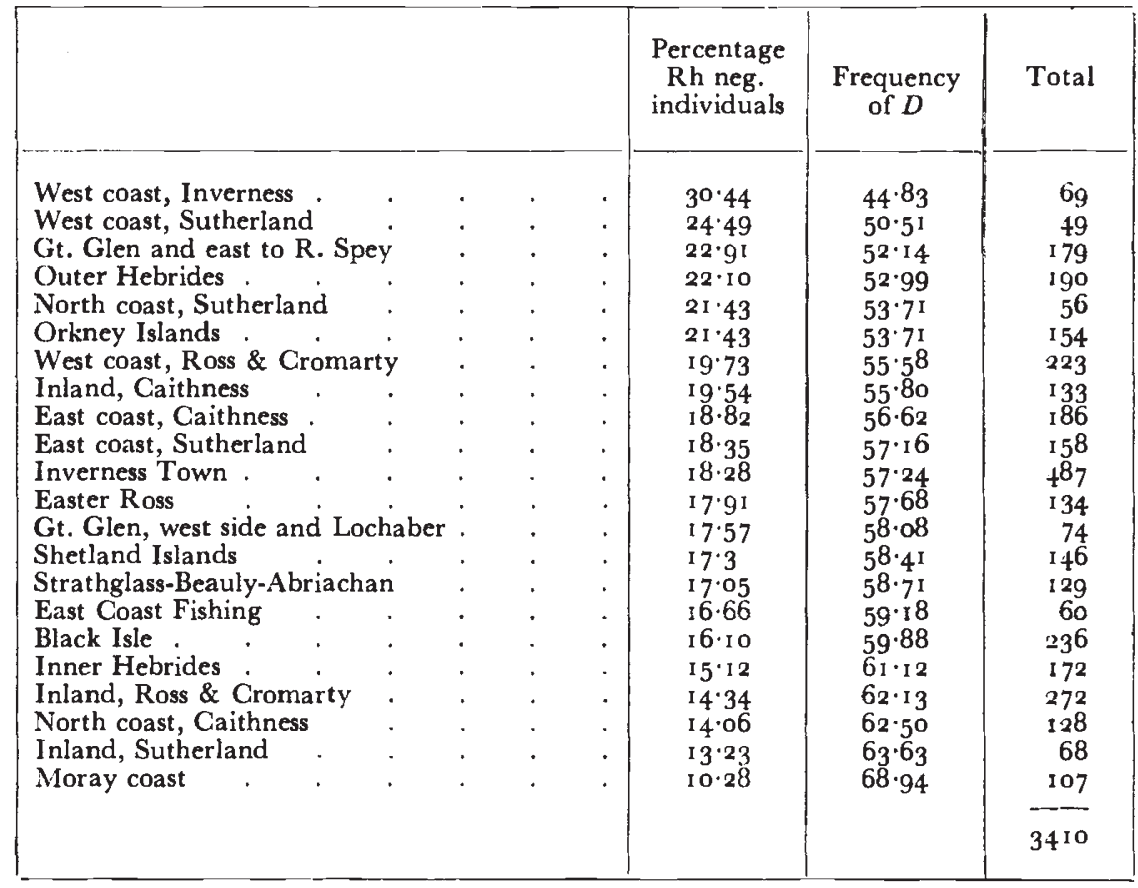

residence, whereas the new figures are based on ancestry. That there is no significant difference between the gene frequencies supports the contention that people now resident in the north of Scotland are very likely to be native to the area.

\section{(v) Frequency of the gene $D$ (map 5)}

The average frequency for the gene $D$ in the British Isles is $55-60$ per cent. and the range found in the north of Scotland varies around this mean. The highest frequency is found on the Moray coast 
(68.94 per cent.), but in general, higher values are found inland, and lower on the coasts. The lowest limit is on the west coast of Invernessshire ( 44.83 per cent.).

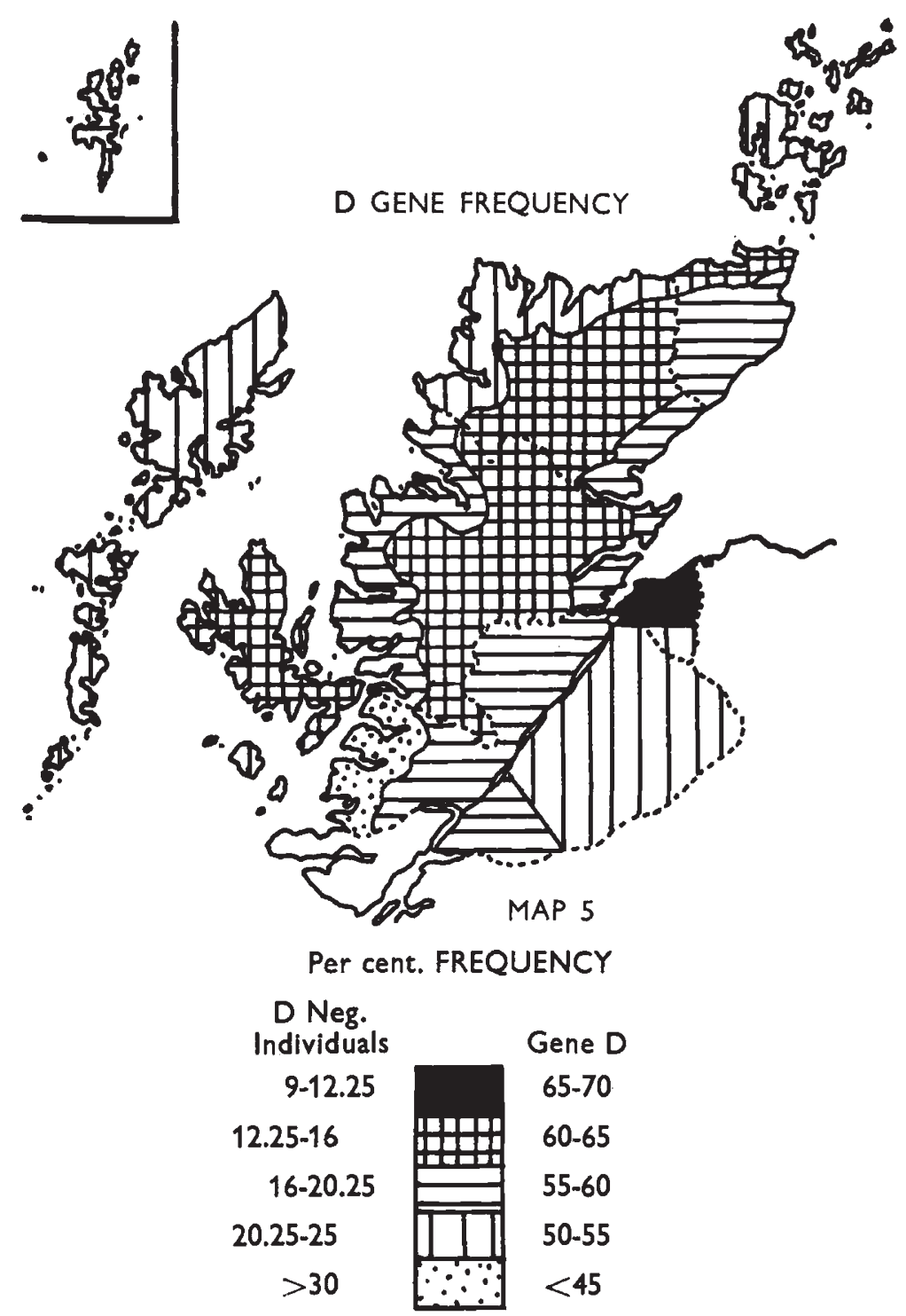

As in the $A B O$ frequency distributions, the Hebrides are unrelated to the adjacent mainland. The value for $D$ is higher in the Inner Hebrides and lower in the Outer Islands.

The frequency of $D$ in the Orkney Islands is identical with that for the north coast of Sutherland, and that for the Shetlands some 5 per cent. higher. 


\section{POINTS OF SPECIAL INTEREST}

1. There is an overall high incidence of the gene $O$ reaching its maximum in the remote parts of the north and west, with reciprocal low values for $A$.

2. Inland Sutherland is unexpectedly lower in $O$ and higher in $A$ than east coast Sutherland.

3. While the general reciprocal relationship of $A / O$ values is found, where the range of figures overlaps with Kopeć's ${ }^{2,}{ }^{3}$ for Great Britain as a whole, those for the gene $A$ in the north of Scotland are pitched on a lower scale.

4. Very low frequencies of $B$ are found on the west coast of Ross and in the Outer Hebrides. High frequencies are found in the Orkney Islands, on the north and east coasts of Caithness and in Easter Ross, with unexpected patches on the west coast of Sutherland, in the StrathglassBeauly-Abriachan area and in the area to the east of the Great Glen.

5. The sample from the "East Coast Fishing" community has an exceptionally high incidence of the gene $B$.

6 . The lowest frequency of the gene $D$ (i.e. the highest incidence of $\mathrm{Rh}$ negative individuals) is found in the extreme west and north.

7. The Hebrides do not continue, but rather repeat the gradients found on the mainland. One would have expected the inner group of islands to resemble the adjacent coastlines of Ross and Invernessshire more closely than they do.

\section{HISTORICAL ORIGIN}

In seeking an interpretation of these observations it seems reasonable to consider the origins of the people who inhabited the north of Scotland at the turn of the present century, since it is at about that time, or before, that the grandparents of most of the people we have been investigating would have been born.

Since the withdrawal of the Norse influence after the Battle of Largs in 1263, the north of Scotland has not received any noticeable influx of population right down to the present day. Indeed the reverse has happened, particularly since the middle of the eighteenth century when, with the abolition of heritable jurisdiction and consequent loss of power to the chiefs, the clan system began to disintegrate. Rack renting and the introduction of large-scale sheep farming started an exodus from the Highlands, which lasted well into the nineteenth century, virtually depopulating many of the glens, and this drift from the rural districts has continued for a variety of reasons ever since.

The brief, and at times conflicting references by Roman historians indicate that there were tribes to be reckoned with north of the Antonine Wall, which extended across the Forth-Clyde isthmus-in fact they were the reason for building the wall-but little can be gleaned from these writings concerning the extent of the territories inhabited by the 
various tribes. The first authoritative statement regarding the population which survives to us, is that made by Bede in A.D. $73 \mathrm{I}$ in his Historia Ecclesiastica, where he recognises four tribes in northern Britain, namely Picts, whom he divides into northern and southern Picts, Scots, Britons and Angles. The Britons and Angles occupied land too far south for present consideration and the Scots, who are believed to have come from Ireland, are mainly of interest as inhabitants of the kingdom known as Dalriada which corresponded to the present county of Argyll touching our region in the west, and which became united with the rest of Pictland in the ninth century A.D. Thus the problem is reduced to that of the origin of the Picts-a problem which is largely unsolved, and is still the subject of much discussion and research among archæologists and prehistorians. ${ }^{13}$

With the last retreat of the Ice Cap and an improvement in climatic conditions, the north of Scotland became a suitable habitat for primitive man. The earliest traces of human beings, in the form of microliths and shell-middens, are to be found around the coasts and these stranddwellers were followed by immigrants who began to clear the forests with their stone axes and form the first true settlements. Some time about 2000-I500 B.c. there arrived on the west coast of Scotland a people who are believed to have come from Iberia. Their settlements are known from the survival of their remarkable chambered tombs and monuments built of huge stones which have given the name megalithic to this cultural period. These tombs are to be found in the Hebrides, on the west and north coasts of Sutherland and at the southern end of the Great Glen. They can be traced up the Glen and, through the breaks in the Monaliadth Hills, east to Strathnairn and the upper reaches of the Spey. From the northern end of the Great Glen they extend up the east coast to Caithness, in places penetrating inland up the river valleys. In the north-east corner of Caithness the concentration of chambered tombs is high, and they are to be found again across the Pentland Firth in Orkney and Shetland (map 6).

At a slightly later date, perhaps commencing about 1800 B.c., a different people, characterised by the beakers which they placed in their short single graves, came to the eastern part of Scotland and have left traces of themselves along the Moray Firth, but very little elsewhere in the northern region.

After these two immigrations and until the influx of the Celtic peoples, which may have begun earlier, but became really significant about 100 B.c., there seem to have been no further incomings into the north. Without becoming involved in discussing the racial composition of the peoples who spoke the Celtic language in its different forms, one can separate the Celtic people in the north of Scotland into $(a)$ those who built the stone strongholds laced together by wooden beams, which, after burning, are described as vitrified forts and are found at each end of the Great Glen and in the country to the east of it, and $(b)$ those who are believed to have arrived a little later and occupied the 
country north and west of the Great Glen. From the nature of the archæological finds, these latter people seem to have come as colonists rather than invaders, bringing their families with them. They built

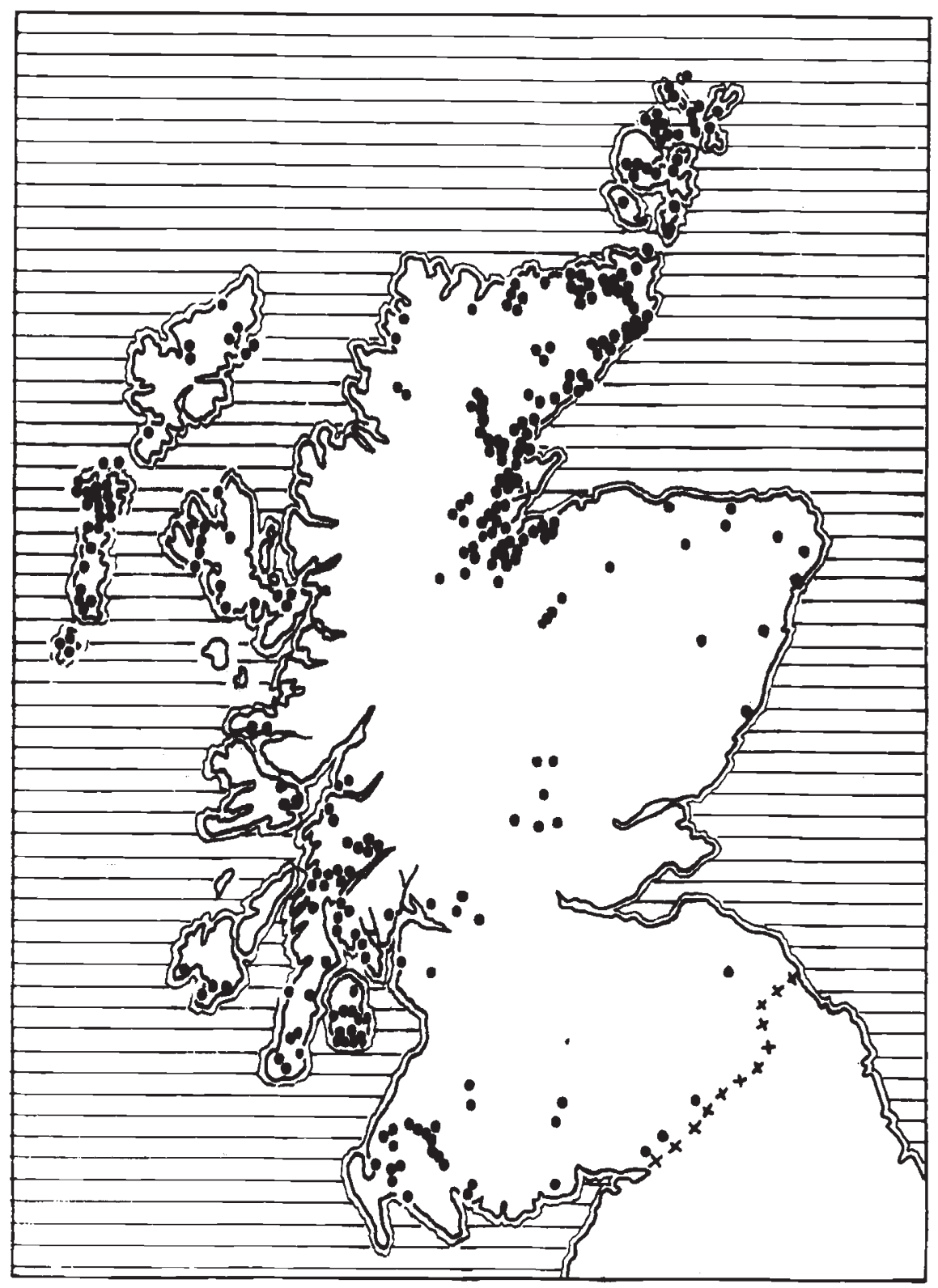

MAP 6

Chambered Cairns in Scotland.

the peculiar tower-shaped structures known as brochs which are to be found in the Western Isles and right up the west coast, reaching their greatest concentration in Sutherland, Caithness, Orkney and Shetland. 
From these beginnings the people referred to by Bede as Picts emerged, probably by a combined process of conquest and assimilation of pre-existing tribes by the Celts. It seems likely that the broch builders were Bede's Northern Picts and the builders of the vitrified forts formed the main body of his Southern Picts.

Lastly came the Norsemen, first as raiders at the end of the eighth century A.D., but soon to come as settlers, particularly in the Orkneys, Shetlands and Hebrides and on the mainland in the north-east corner of Caithness. Their influence extended right down the west coast and in the east as far south as the Moray Firth, although in these parts they seem to have been overlords rather than colonists.

From the ancient tribes, the clan system evolved, recognising a chief who had rights over the people in his territory, with the result that families tended to stay where they were, living a life based on the land where they were born.

\section{ASSESSMENT OF RESULTS \\ (1) The Celtic element}

From the figures found for the incidence of the gene $O$ and comparison with figures published for other parts of the British Isles, it would seem that where the influence of peoples speaking some form of the Celtic language is highest, there the incidence of $O$ is also highest. Thus outside Scotland the greatest numbers of group $O$ individuals are to be found in Ireland and Wales. The Welsh values are comparable to those found south and east of the Great Glen, where the Celtic language spoken was also the Brittonic or $\mathrm{P}$ form. In Scotland, however, it is not at all clear what proportion of the early Celtic speaking population was immigrant and what was an old established people who adopted the language of the newcomers.

In the extreme north and west, where the Gaelic is derived from Q-Celtic and has Irish affinities, the very high $O$ gene frequencies are also more comparable with Irish values. The highest values of $O$ in north Scotland also correspond to the regions where the brochs are to be found, but it is perhaps jumping to conclusions to suggest a correlation between them.

The reversal of expected values for $O$ and $A$ between inland and east coast Sutherland can probably be explained by movement of people within historic times. Early in the nineteenth century largescale sheep farming was introduced into Sutherland, and the crofters were evicted from their homes in the glens. Those who did not emigrate were forced to settle on a narrow strip of land on the east coast where they tried to make a living from the sea, and in their place were introduced shepherd families from the Border country between Scotland and England.

\section{(ii) The Megalithic element}

Comparison between map 4 of the distribution of the gene $B$ and map 6 of the megalithic chambered tombs, shows an interesting 
similarity. Both have a high concentration in the north-east corner of Caithness and down the east coast to the Moray Firth. On the west coast of Sutherland where the frequency of $B$ is high, megalithic tombs have been found, but none is recorded on the west coast of Ross where the value for $B$ falls off markedly. Where the high frequency of $B$ penetrates inland up the River Glass, past Beauly, and to the Abriachan district there also the tombs are to be found. South-east of the Great Glen there are some of the best-known chambered tombs, notably at Glava on the River Nairn, and as far south as Avielochan on the Spey, and again in this area the incidence of $B$ is high. Is it too much to suggest that this correlation is more than coincidence? In the Hebrides and Shetland Islands there are numbers of megalithic monuments, but the incidence of $B$ is quite low, particularly in the Outer Hebrides. There is reason to believe, however, that the more remote islands were deserted by the first century A.D., and, if the megalithic builders were in fact a race of high group $B$ people, this too would fit. Lastly, it is thought that the cult of building these tombs and monuments reached Scotland from Iberia via the west coast of Britain, which would include Wales, where again pockets of high group $B$ people are found today, and where there are also megalithic monuments.

\section{(iii) The Norse element}

Thus it is postulated that when the Norsemen came to the north of Britain they found a land populated by the survivors of the earliest strand dwelling colonists, to whom had been added the megalithic builders (? group $B$ ) and superimposed on these the Celtic peoples, broch-builders (? group $O$ ) to the north of the Great Glen, and vitrified fort builders to the south-east-in effect the Picts.

At the height of Norse power in the eleventh century A.D., the Orkney and Shetland Islands, the north-east of Caithness and the Island of Lewis in the Outer Hebrides were virtually Norse colonies. As one progressed inland and along the coasts west and south from Caithness the Norse influence upon the population decreased, and while there is ample evidence of penetration in the survival of place names and burial sites, it is probable that the Norsemen made their presence felt more as overlords than as settlers who intermarried with the native population. The regions of highest $A$ frequency do correspond to some extent with the localities where there is more evidence of Norse settlement, however, and there may be a relationship. In his studies of rural Wales, Watkin ${ }^{7,}{ }^{8}$ has mentioned a similar correlation between high $A$ frequency in south-east Pembroke and signs of a Viking settlement in the same area. This high incidence of $A$ in Pembroke has been further confirmed by other recent work (Kopeć).$^{2,3}$

In the north of Scotland the lowest frequency for the gene $D$ (i.e. the highest percentage of $\mathrm{Rh}$ negative individuals) has been found on the west coast of Inverness-shire with an overall tendency for low 
values in the extreme west and north. This agrees with Mourant's general finding of a decreasing value for $D$ as one goes westwards across Europe and the fact that in the north of Scotland low $D$ areas also correspond to high $O$ areas is probably fortuitous.

With regard to the high gene $B$ frequency in the "East Coast Fishing " community, more figures should be collected and it would be interesting to compare these with fisher folk elsewhere in the British Isles.

\section{SUMMARY}

A study has been made of the $A B O$ and Rhesus $(D)$ blood groups of 300 people from the Orkney and Shetland Islands and 3 I Io people who were born within the five northern counties of Scotland, and whose grandparents were also born within the area.

Unusually high gene $O$ and both low and high gene $B$ frequencies were found in certain districts.

Very low $D$ gene frequencies were found mainly in the extreme west and north.

The origins of the population of the area are briefly reviewed and some ideas put forward to suggest a correlation between ancient peoples and present blood group findings.

Acknowledgments.-I wish to thank Dr I. A. Cook, for his help and encouragement; Dr H. J. R. Kirkpatrick who was the initiator of the investigation; Dr Ada Kopeć for calculating most of the gene frequencies; Dr D. Mackay for application of the $\chi^{2}$ test to table 2; Dr A. E. Mourant for his enthusiastic interest; Professor Stuart Piggott for advice on prehistory; Mrs Gladys McAvoy, Mrs Helen Morison and other ladies for collecting information and preparing cards; and all blood donors and patients who willingly disclosed particulars of their ancestry.

I am also indebted to Dr J. Wallace, West of Scotland Blood Transfusion Service, for allowing me to use blood group lists of the Orkney and Shetland islanders. These blood samples had been obtained in connection with a survey sponsored by the Multiple Sclerosis Society.

All blood grouping tests were carried out by laboratory technicians of the Scottish National Blood Transfusion Association without whose cooperation this work would not have been possible.

Financial assistance was provided by the Scottish National Blood Transfusion Association.

Map 6 is from Prehistoric Peoples of Scotland. Ed. by Stuart Piggott. Published by Routledge and Kegan Paul. Reproduced by kind permission of author and publisher.

\section{REFERENCES \\ Blood Groups}

I. FISHER, R. A., AND TAYlor, G. L. i940. Scandinavian influence in Scottish Ethnology. Nature, 145, 590.

2. KOPEĆ, ADA C. I956. Blood groups in Great Britain. Adv. Sci., Lond., $X I I I$, No. 5 I, 200-203.

3. KOPEĆ, ADA c. 1964. Communication to the British Association for Adrancement of Science, Southampton.

4. Mourant, A. E. 1954. Distribution of the Human Blood Groups. Oxford, Blackwell. 
5. MOURANT, A. E., KOPEĆ, A. C., AND DOMANIEWSKA-SOBCZAK, K. I958. The $A B O$ Blood Groups. Oxford, Blackwell.

6. Mourant, A. E., AND WATKIN, I. M. 1952. Blood groups, anthropology and language in North Wales and the Western countries. Heredity, 6, 13-56.

7. WATKIN, I. M. 1956. ABO blood groups and racial characteristics in rural Wales. Heredity, ro, I6 I-193.

8. WATKIN, I. M. 1960. A Viking settlement in little England beyond Wales: ABO blood-group evidence. Man. LX, Art. I93.

\section{Prehistory}

9. CHILde, v. GoRdon. 1935. Prehistory of Scotland. Paul, Trench and Trubner. IO. CHILDE, v. GORDON. 1946. Scotland before the Scots. Methuen.

I1. Piggott, stuart. 1954. The Neolithic Cultures of the British Isles. Cambridge University Press.

12. Piggott, stuart. 1962. Prehistoric Peoples of Scotland. Routledge and Kegan Paul.

13. WAinright, F. т. 1955. The Problems of the Picts. Nelson.

\section{History}

14. Dickinson, Wm. Croft. 1961. A New History of Scotland. Nelson.

15. Macdonald, D. F. I937. Scotland's Shifting Population, 1770-1850. Jackson.

i6. RAIt, ROBERT, AND PRYDE, GeORge S. 1954. Scotland. Benn. 